\title{
Retinopathy of Prematurity: Its incidence, prevalence and risk factors in a teaching hospital in South India
}

\author{
Sreenivasan V K ${ }^{1}$, Aparna Gulvadi² \\ ${ }^{1}$ Associate Professor, Department of Paediatrics, Amala Institute of Medical Sciences, Trichur, Kerala, India. ${ }^{2}$ Associate Professor, Department of Paediatrics, \\ Amala Institute of Medical Sciences, Trichur, Kerala, India.
}

\section{Abstract}

Background: Retinopathy of prematurity (ROP) is an important cause of preventable blindness in the world. In India also as more and more premature babies are being saved the incidence is on the rise. Aim of this study is to know the incidence, prevalence and risk factors of ROP in preterm babies with birth weight $<1750$ gms and /or gestational age < 35 weeks in a teaching hospital. Subjects and Methods: This study was conducted at Amala Institute of Medical Sciences from August 2016 to July 2018. All preterm babies < 1750 gms and/ or gestational age < 35 weeks and babies > 35 weeks and > 1750 gms with significant risk factors were screened for ROP. Results: Out of 202 babies, 180 babies fulfilled the criteria and completed the study. 12 babies did not meet the follow up criteria and 10 babies died before screening in the hospital. Out of 180 babies, 12 babies were found to have ROP with a prevalence rate of $6.7 \%$. Conclusion: ROP is an important cause of preventable blindness in these vulnerable babies. Timely diagnosis and intervention will help to prevent the same.

Keywords: Retinopathy of prematurity, risk factors, South India.

Corresponding Author: Dr Sreenivasan V K, Associate professor, Department of Paediatrics, Amala Institute of Medical Sciences, Trichur, Kerala, India.

Received: May 2019

Accepted: May 2019

\section{Introduction}

Retinopathy of Prematurity (ROP) is a vasculo proliferative disorder of the developing retina of preterm low birth weight babies that can lead to significant visual handicap. ${ }^{[1]}$ ROP was first reported by Terry in $1942 .{ }^{[2]}$ ROP evolves over first few weeks after birth and hence it gives only a limited window for screening and appropriate intervention. The incidence of ROP in our country varies in different studies from $28 \%$ to as high as $54 \% .^{[3]}$ Incidence in developed countries like USA is around 15 to $20 \% .4$ As more and more extreme premature babies are being saved by modern neonatal care starting from antenatal steroids to tertiary neonatal care, the incidence is likely to rise further. Robust screening for ROP, early detection and intervention programme is mandatory in every institution managing these babies. ${ }^{[12,13]}$

\section{Subjects and Methods}

This study was conducted at Amala Institute of Medical Sciences, Trichur. Total babies enrolled were 202.

Inclusion criteria: Preterm babies with gestational age $<35$ weeks and or birth weight $<1750$ gms. Babies between 1750 to 2000 gms or between 35 and 37 weeks with high risk factors like respiratory distress, sepsis, apnea, blood transfusion, prolonged oxygen therapy.

Exclusion criteria: Babies where consent for the study could not be obtained and babies who died before screening could be done.

Initial screening was done within in 4 weeks of life. In babies 28 weeks or less of gestation, initial screening done earlier within 3 weeks of life. Screening was performed by a trained specialist under strict aseptic precautions using indirect binocular ophthalmoscope with +20 dioptre lens.

If no ROP was detected at initial examination, the infants were reevaluated every 2 weeks till vascularisation was complete. I f ROP was detected it was graded using the International Classification of ROP (ICROP) guidelines. Follow up was done based on severity and location as given in table 1 below. ${ }^{[15]}$

\section{Results}

202 babies were enrolled in the study out of which 180 fulfilled the criteria and completed the study. 10 babies died during the early neonatal period and 12 babies did not complete follow up criteria. [Table2]. Out of these 12 babies with ROP, 6 babies had Stage 1 and 6 babies had Stage 2. No babies had Stage 3 or 4 or Plus disease. 
Table 1: Treatment of ROP

\section{Early Treatment of Retinopathy of Prematurity (ETROP) Classification:}

Type 1 ROP should be treated:

Zone I any stage of ROP with plus disease

Zone I Stage 3 ROP with or without plus disease

Zone II Stage 2 or 3 ROP with plus disease

Type 2 should be observed, and only undergo treatment if it progresses to type I or threshold disease:

Zone II Stage 1 or 2 ROP without plus disease

Zone II Stage 3 ROP without plus disease

\begin{tabular}{|l|l|l|}
\hline Table 2: Incidence of Retinopathy of Prematurity \\
\hline ROP & Number & Percentage \\
\hline Present & 12 & 6.7 \\
\hline Absent & 168 & 93.3 \\
\hline Total & 180 & 100 \\
\hline
\end{tabular}

Out of 180 babies 95 were females and 85 were males. The birth weight of the babies ranged from $720 \mathrm{~g}$ to $2600 \mathrm{~g}$ with a mean birth weight of $1210+280 \mathrm{~g}$. The birth weight of ROP babies ranged from 720 to $1350 \mathrm{~g}$ (mean $880+220 \mathrm{~g}$ ) while without ROP, birth weight ranged from $1200 \mathrm{~g}$ to $2600 \mathrm{~g}$ (mean $1430+350 \mathrm{~g})$. In babies with birth weight below $1000 \mathrm{~g}$ the incidence was $100 \%$ while incidence in low birth weight babies $(1000-1499 \mathrm{~g})$ the incidence was $7.69 \%$ [Table 3]. In babies above $1500 \mathrm{~g}$ there was no ROP.

Table 3: Incidence of Birth weight and ROP

\begin{tabular}{|l|l|l|l|}
\hline Birth weight & $\begin{array}{l}\text { ROP } \\
\text { Present }\end{array}$ & $\begin{array}{l}\text { ROP } \\
\text { Absent }\end{array}$ & Total \\
\hline$<1000$ & $8(100 \%)$ & $0(0 \%)$ & 8 \\
\hline $1000-1499$ & $4(7.7 \%)$ & $48(92.3 \%)$ & 52 \\
\hline$\geq 1500$ & $0(0 \%)$ & $120(100 \%)$ & 120 \\
\hline Total & $12(6.7 \%)$ & $168(93.3 \%)$ & 180 \\
\hline
\end{tabular}

Fisher's exact test $\mathrm{p}$ value $=0.001$

The gestational age of ROP babies ranged from 26- 32 weeks (mean 27.4+1.72), while non ROP babies ranged from 27-37(30.7+2.9) weeks. The incidence of ROP in babies < 28 weeks was $50 \%$ as compared to $7.69 \%$ in the group 28-34 weeks. None of the babies above 35 weeks had ROP.

\begin{tabular}{|l|l|l|l|}
\hline Table 4: Incidence of gestational age and ROP \\
\begin{tabular}{|l|l|l|l|}
\hline $\begin{array}{l}\text { Gestational age } \\
\text { (weeks) }\end{array}$ & $\begin{array}{l}\text { ROP } \\
\text { Present }\end{array}$ & $\begin{array}{l}\text { ROP } \\
\text { Absent }\end{array}$ & Total \\
\hline$<28$ & $4(50 \%)$ & $4(50 \%)$ & 8 \\
\hline $28-34$ & $8(7.69 \%)$ & $96(92.3 \%)$ & 104 \\
\hline $35-37$ & $0(0 \%)$ & $68(100 \%)$ & 68 \\
\hline Total & $12(6.7 \%)$ & $168(93 . \%)$ & 180 \\
\hline
\end{tabular}
\end{tabular}

Fisher's exact test $\mathrm{p}$ value $=0.001$

In our study 8 babies (28.6\%) of 28 babies who presented with shock and poor perfusion at birth developed ROP. 12 babies $(30 \%)$ out of 40 babies with sepsis developed ROP. None of the 64 babies whose mothers had PIH developed ROP. Only 12 babies (7.5\%) of 172 babies who received phototherapy had ROP. 12 babies (13.6\%) out of 88 babies who developed apnea of prematurity had ROP. Incidence of ROP in babies with RDS was $12(30 \%)$ out of 40 babies, 8 babies who received blood transfusion out of 12 developed
ROP. 12 babies (15,8\%) out of 76 babies who received prolonged oxygen therapy had ROP. Only 8 babies (10\%) of 80 whose mothers received antenatal steroids developed ROP4.

\begin{tabular}{l}
\hline Table 5: Co relationship between risk factors and ROP \\
\begin{tabular}{|l|l|l|l|l|}
\hline Risk factor & $\begin{array}{l}\text { ROP } \\
\text { Present }\end{array}$ & $\begin{array}{l}\text { ROP } \\
\text { Absent }\end{array}$ & $\begin{array}{l}\text { Total } \\
\text { p value } \\
\text { (fisher's } \\
\text { exact } \\
\text { test) }\end{array}$ \\
\hline Shock & $8(28.6 \%)$ & $20(71.4 \%)$ & 28 & \multirow{2}{*}{0.0001} \\
\hline Sepsis & $12(30 \%)$ & $28(70 \%)$ & 40 & \\
\hline PIH & $0(0 \%)$ & $64(100 \%)$ & 64 & \\
\hline Phototherapy & $12(7.5 \%)$ & $160(92.5 \%)$ & 172 & \\
\hline Apnoea & $12(13.6 \%)$ & $76(86.4 \%)$ & 88 & \\
\hline RDS & $12(30 \%)$ & $28(70 \%)$ & 40 & \\
\hline $\begin{array}{l}\text { Blood } \\
\text { Transfusion }\end{array}$ & $8(66.7 \%)$ & $4(33.3 \%)$ & 12 & \\
\hline $\begin{array}{l}\text { Oxygen } \\
\text { Therapy }\end{array}$ & $12(15.8 \%)$ & $64(84.2 \%)$ & 76 & \\
\hline $\begin{array}{l}\text { Antenatal } \\
\text { Steroids }\end{array}$ & $8(10 \%)$ & $72(90 \%)$ & 80 & \\
\hline
\end{tabular}
\end{tabular}

\section{Discussion}

Retinopathy of prematurity (ROP) is a rapidly evolving disease of the retinal vessels due to abnormal vasoproliferation. It has become one of the main causes for preventable blindness in children. ${ }^{[5]}$ Even in a developing country like India as more and more preterm babies are being saved by modern medical care, the incidence is on the rise. In our study, all preterm babies $<35$ weeks and/ or weighing <1750 g and babies between $1750 \mathrm{~g}$ to $2000 \mathrm{~g}$ and babies up to 37 weeks with high risk factors were screened for ROP by a single retinal specialist. In United Kingdom, babies less than 32 weeks and less than $1500 \mathrm{~g}$ are screened for ROP. In India larger and mature babies have been reported to have ROP and hence there are recommendations to screen babies up to $2000 \mathrm{~g}$ and $<37$ weeks. ${ }^{[11-13]}$

\begin{tabular}{|c|c|c|}
\hline \multicolumn{3}{|c|}{ Table 5: Classification of ROP } \\
\hline \multirow[t]{3}{*}{ Location } & Zone 1 & $\begin{array}{l}\text { Circle with optic disc as centre and a } \\
\text { radius with twice the distance from } \\
\text { optic disc to fovea }\end{array}$ \\
\hline & Zone 2 & $\begin{array}{l}\text { Concentric circle from edge of zone } 1 \\
\text { from oraserrata nasally and equator } \\
\text { temporally. }\end{array}$ \\
\hline & Zone 3 & $\begin{array}{lllll}\text { Lateral crescent from zone } 2 \text { to } \\
\text { oraserrata temporally }\end{array}$ \\
\hline \multirow[t]{5}{*}{ Severity } & Stage 1 & $\begin{array}{l}\text { Presence of thin white demarcation } \\
\text { separating vascular and avascular retina }\end{array}$ \\
\hline & Stage 2 & $\begin{array}{l}\text { Additional depth and width to the above } \\
\text { line to become a ridge }\end{array}$ \\
\hline & Stage 3 & $\begin{array}{l}\text { Presence of extra retinal fibro vascular } \\
\text { proliferation with abnormal vessels and } \\
\text { fibrous tissue extending from ridge to } \\
\text { vitreous and the ridge has a velvety } \\
\text { appearance with a ragged border }\end{array}$ \\
\hline & Stage 4 & $\begin{array}{l}\text { Partial retinal detachment beginning at } \\
\text { the ridge where the retina got pulled } \\
\text { anteriorly into the vitreous by the fibro } \\
\text { vascular ridge not involving macula } \\
\text { (4A) and involving macula (4B) }\end{array}$ \\
\hline & Stage 5 & Complete retinal detachment \\
\hline $\begin{array}{l}\text { Plus } \\
\text { disease }\end{array}$ & \multicolumn{2}{|c|}{$\begin{array}{l}\text { disease is an indication of5activity and is characterized } \\
\text { by the presence }\end{array}$} \\
\hline
\end{tabular}




\begin{tabular}{|l|l|}
\hline $\begin{array}{l}\text { Is an indication of activity and is characterised by } \\
\text { dilatation and tortuosity of retinal vessels at posterior } \\
\text { pole of eye. Also associated with pupillary rigidity and } \\
\text { vitreous haze }\end{array}$ \\
\hline
\end{tabular}
Incidence of ROP in studies done in India varied from $18 \%$ to $46 \% \cdot{ }^{[7-10]}$ In our study the incidence of ROP was $6.7 \%$ only. This is comparatively low as compared to many studies. In a study from KMCH, Tamilnadu, ${ }^{[9]}$ The incidence was $19.2 \%$. In our study we had taken weight criteria of $1750 \mathrm{~g}$ and 35 weeks as compared to $1500 \mathrm{~g}$ and 32 week in their study. Another study from Central India by Bodhrajdhavan et al, ${ }^{[6]}$ from a rural tertiary care hospital reported an incidence of $22 \%$ (11 out of 50 babies). Incidence in India is likely to increase as more and more preterm babies are being saved by modern neonatal care. In UK also the incidence is increasing. In their study by Painter et al, ${ }^{[16]}$ Incidence and treatment of ROP in England between 1990 and 2011, there is an increase from $12.8 \%$ per $1000 \mathrm{LBW}$ to 125.5 per $1000 \mathrm{LBW}$ in $2011 .^{[16-18]}$

Incidence of ROP in India is quoted between 38 to $51.9 \%$ in LBW babies. Out of 30 million annual live births, approximately $9 \%$ of newborn are $<2000$ g. ${ }^{[19]}$ In our study all babies below $1000 \mathrm{~g}$ ( 8 out of 8 babies) had evidence of ROP. All these babies had Stage 1 and stage 2 ROP and were treated appropriately. None of these babies needed laser therapy. 4 (7\%) out of 52 babies between $1000 \mathrm{~g}$ and $1499 \mathrm{~g}$ had ROP. No babies above $1500 \mathrm{~g}$ had ROP. In a study by $\mathrm{R}$ Nikhil and others, from Tamilnadu, reported incidence of $48 \%<1000 \mathrm{~g}$ (12 out of 25 babies), $9.98 \%$ in $1000-1500 \mathrm{~g}$ ( 3 out of 43) and none above $1500 \mathrm{~g}$. In other studies from various parts of India. ${ }^{[6,8-10]}$ also reported similar pattern with regard to both gestational age and birth weight. This is reassuring though the present guidelines recommends screening of all babies below 2000g. ${ }^{[11-14]}$ With regard to risk factors and ROP, out of 28 babies who presented with shock and poor perfusion 8(28.6\%) developed ROP. ${ }^{[12]}$ (30\%) babies out of 40 babies who had RDS developed RDS. Indirectly all 12 babies who developed ROP had RDS. This is because RDS is seen in more premature babies.

Incidence of ROP in cases where antenatal steroids were given to mothers was less $8(10 \%)$ out of 80 . This reinforces the role of antenatal steroids in anticipated preterm labour. In our state this practice is regularly followed by obstetricians and that might be one of the reasons for reduced incidence of ROP in our study. 8 (66.7\%) out of 12 babies who received blood transfusion developed ROP. None of the 64 babies born to mothers who had PIH developed ROP. ${ }^{[19]}$ This may be attributed to closely monitoring and early diagnosis in mother due to regular antenatal care. The link between oxygen therapy and ROP is well established. ${ }^{[1,20,21]}$ Use of oxygen should be judiciously used right from resuscitation and use of oxygen blenders is strongly recommended in neonatal units. In our study 12 babies $(15.8 \%)$ out of 76 babies who received prolonged oxygen therapy developed ROP. In other words none of the babies who did not receive oxygen developed ROP. Thus oxygen therapy, RDS and blood transfusion are the most important risk factors for ROP. NEOPROM collaborative study which is a met analysis of 5 trials concluded that higher oxygen saturation (91-95\%) was associated with more ROP where as lower saturation (88$89 \%$ ) was associated with more deaths and NEC. ${ }^{[23-25]}$

\section{Conclusion}

This study was conducted to identify the incidence and association of risk factors associated with this condition. As ROP is a rapidly evolving disease the window for diagnosis is very important. In our study also the prevalence of ROP with decreasing gestational age and birth weight was seen. This is a well documented fact. There was also increased association with babies who received prolonged oxygen therapy, had shock, RDS and those who received blood transfusion. As the number of preterm babies surviving in our country is increasing we should have a robust screening programme for ROP as ROP is one of the leading causes of preventable blindness in the world.

\section{References}

1. Campbell K. Intensive oxygen therapy as a possible cause of retrolental fibroplasia; a clinical approach.

2. Terry TL. Extreme prematurity and fibroblastic overgrowth of persistent vascular sheath behind each crystalline lens. I. Preliminary report. Am J Ophthalmol. 1942;25:203-4

3. Med J Austral. 1951; 2(2):48-50. Gopal L, Sharma T, RamachandranS,Shanmugasundaram R, Asha V. Retinopathy of prematurity. A study. Indian J Ophthalmol. 1995; 43:50-61. 3.

4. ParvenSen, ChetanRao, NishantBansal. Retinopathy of Prematurity: an update. Sci j Med \& Vis Res Foun 2015: XXXIII: 93-96.

5. Pascolini D, Mariotti SP. Global estimates of visual impairment: 2010. Brit J Ophthalmol. 2012; 96(5):614-8Heath P. Pathology of retinopathy of prematurity, RLF. Am J Ophthalmol. 1951; 34:124968.

6. Bodhrajdhawan, Rekhakhandelwal, Kanavgupta. Retinopathy of Prematurity- Prevalence and High risk characteristics in a Rural Tertiary care Hospital in Central India. Indian journal of neonatal Medicine and Research. 2016 July; vol-4(3): P001-P005.

7. Ahmed MA, Duncan M, Kent A, NICUS Group. Incidence of retinopathy of prematurity requiring treatment in infants born greater than 30 weeks' gestation and with a birth weight greater than $1250 \mathrm{~g}$ from 1998 to 2002: A regional study. J Paediatr Child Health. 2006; 42(6):337-40.

8. Gupta VP, Dhaliwal U, Sharma R, Gupta P, Rohatgi J. Retinopathy of prematurity risk factors. Indian J Pediatr. 2004; 71(10):887-92.

9. Rekha S, Battu RR, Chandrasekhara MK. Retinopathy of prematurity a preliminary report. Indian Pediatr. 1992; 29(5):623-26.

10. R. Nikhil, k. Rajendran, Balakrishnan. Prevalence and outcome of retinopathy of prematurity in preterm infants with low birth weight at KMCH, Tamilnadu, India: Int J ContempPediatr 2019 Mar: 6(2); 264268.

11. Jalali S, Matalia J, Hussain A, Anand R. Modification of screening criteria for retinopathy of prematurity in India and other middleincome countries. Am J Ophthalmol. 2006; 141(5):966-68.

12. Pejawar R, Vinekar A, Bilagi A. National Neonatology Foundation's Evidence-based Clinical Practise Guidelines (2010), Retinopathy of Prematurity, NNF India, New Delhi 2010:253-62.

13. Vinekar A, Gilbert C, Dogra M, Kurian M, Shainesh G, Shetty B, Bauer N. The KIDROP model of combining strategies for providing retinopathy of prematurity screening in underserved areas in India using wide-field imaging, tele-medicine, non-physician graders and smart phone reporting. Indian J Ophthalmol. 2014; 62(1):41-9.

14. AnandVinekar, ChaitraJayadev, ShwethaMangalesh, Mathew Kurian, 
MangatDogra, Noe Bauer and BhujangShetty. Initiating Retinopathy of Prematurity Screening before Discharge from the Neonatal Care Unit: Effect on Enrolment in Rural India. Indian Pediatrics: Volume 53, Supplement 1; November 2016.

15. Uparkar M, Sen P, Rawal A, Agarwal S, Khan B, Gopal L. Laser photocoagulation (810 $\mathrm{nm}$ diode) for threshold retinopathy of prematurity: a prospective randomized pilot study of treatment to ridge and avascular retina versus avascular retina alone. IntOphthalmol. 2011; 31(1):3-8.

16. Painter SL, Wilkinson AR, Desai P, Goldacre MJ, Patel CK. Incidence and treatment of retinopathy of prematurity in England between 1990 and 2011: database study. Br J Ophthalmol. 2015 Jun; 99(6):807-11. doi: 10.1136/bjophthalmol-2014-305561. Epub 2014 Nov 26.

17. Blencowe H, Cousens S, Oestergaard MZ, Chou D, Moller AB, Narwal R et al. National, regional, and worldwide estimates of preterm birth rates in the year 2010 with time trends since 1990 for selected countries: a systematic analysis and implications. Lancet. 2012 Jun 15;379(9832):2162-72

18. Cheuk-Ling Yim, Matthew Tam, Hiu-Lam Chan, Shu-Min Tang, Sunny C L Au, Wilson W K Yip, Simon T C Ko, Shi Song Rong, Li Jia Chen1, Danny Siu-Chun Ng, Jason C S Yam. Association of antenatal steroid and risk of retinopathy of prematurity: a systematic review and meta-analysis: British Journal of Ophthalmology, Vol 102. Issue 10

19. Bharti Mehta, Vijay Kumar, SumitChawla, SandeepSachdeva, and DebjyotiMahopatra. Hypertension in Pregnancy: A Community-Based Study. Indian J Community Med. 2015 Oct-Dec; 40(4): 273-278.

20. Kinsey VE, Jacobus JT, Hemphill F. Retrolental fibroplasia: a cooperative study of retrolental fibroplasia and the use of oxygen. Arch Ophthalmol. 1956; 56:481-543.

21. Kong L, Fry M, Al-Samarraie M, Gilbert C, Steinkuller PG. An update on progress and the changing epidemiology of causes of childhood blindness worldwide. J AAPOS. 2012;16(6):501-7

22. Patz A, Hoeck LE, de la Cruz E. Studies on the effect of high oxygen administration in retrolental fibroplasia. 1. Nursery observations. Am J Ophthalmol. 1952; 35:1248-53.

23. Markestad T, Kaaresen PI, Ronnestad A, Reigstad H, Lossius K, Medb $\varnothing$ S, et al. Early death, morbidity, and need for treatment among extremely premature infants. Pediatr. 2005; 115(5):1289-98.

24. Palmer EA, Flynn JT, Hardy RJ, Phelps DL, Phillips CL, Schaffer DB, et al. Incidence and early course of retinopathy of prematurity. Ophthalmol. 1991; 98(11):1628-40.

Copyright: (C) the author(s), 2019. It is an open-access article distributed under the terms of the Creative Commons Attribution License (CC BY 4.0), which permits authors to retain ownership of the copyright for their content, and allow anyone to download, reuse, reprint, modify, distribute and/or copy the content as long as the original authors and source are cited.

How to cite this article: Sreenivasan VK, Gulvadi A. Retinopathy of Prematurity: Its incidence, prevalence and risk factors in a teaching hospital in South India.Asian J. Med. Res. 2019;8(2):PE01-PE04.

DOI: dx.doi.org/10.21276/ajmr.2019.8.2.PE1

Source of Support: Nil, Conflict of Interest: None declared.

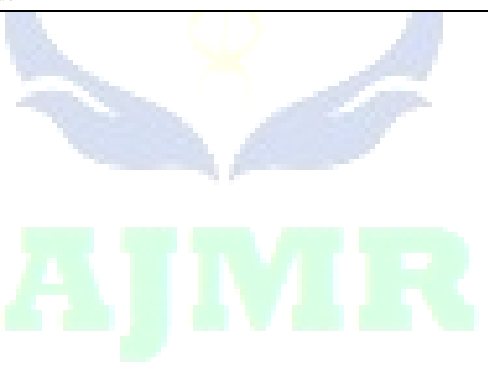

